\section{Scaling and root planing with and without periodontal flap surgery}

\author{
Caffesse RG, Sweeney $P L$ and Smith BA: Scaling and root planing with and \\ without periodontal flap surgery. J Clin Periodontol 1986; 13: 205-210.
}

\begin{abstract}
Complete removal of calculus is a primary part of achieving a "biologically acceptable" tooth surface in the treatment of periodontitis. Rabbani et al. reported that a single episode of scaling did not completely remove subgingival calculus and that the deeper the periodontal pocket, the less complete the calculus removal. The purpose of the present study was to evaluate the effectiveness of scaling relative to calculus removal following reflection of a periodontal flap. Each of 21 patients who required multiple extractions had 2 teeth scaled, 2 teeth scaled following the reflection of a periodontal flap, and 2 teeth serve as controls. Local anesthesia was used. Following extraction, the \% of subgingival tooth surfaces free of calculus was determined using the method described by Rabbani with a stereomicroscope. Results showed that while scaling only (SO) and scaling with a flap (SF) increased the $\%$ of root surface without calculus, scaling following the reflection of a flap aided calculus removal in pockets $4 \mathrm{~mm}$ and deeper. Comparison of SO versus SF at various pocket depths for $\%$ of tooth surfaces completely free of calculus showed 1 to $3 \mathrm{~mm}$ pockets to be $86 \%$ versus $86 \%, 4$ to $6 \mathrm{~mm}$ pockets to be $43 \%$ versus $76 \%$ and $>6 \mathrm{~mm}$ pockets to be $32 \%$ versus $50 \%$. The extent of residual calculus was directly related to pocket depth, was greater following scaling only, and was greatest at the CEJ or in association with grooves, fossae or furcations. No differences were noted between anterior and posterior teeth or between different tooth surfaces.
\end{abstract}

Raul G. Caffesse', Patrick L. Sweeney ${ }^{2}$ and B. A. Smith ${ }^{1}$

'Department of Periodontics, The University of Michigan School of Dentistry, Ann Arbor. Michigan 48109, USA. 'Present address: 20700 Vernier Road, Harper Woods, Michigan 48225, USA
Key words: Scaling - access flap - calculus - pocket depth.

Accepted for publication January 30, 1985
The primary etiologic agents in periodontitis are bacterial plaque and calculus. Correlation of supragingival plaque and calculus with gingivitis and periodontitis has been demonstrated in several studies (Lindhe et al. 1973, 1975, Loe et al. 1965, Theilade et al. 1966). Scaling and root planing are widely used techniques in periodontal therapy to remove irritants from the surfaces of the teeth and also to reduce tooth suface roughness which may facilitate the accumulation of irritants (Waerhaug 1956).

It has become increasingly evident that the most important aspect of periodontal therapy is the removal of all accretions from tooth surfaces exposed by periodontal disease (Aleo \& Vandersall 1980, Axelsson \& Lindhe 1978, Caton et al. 1982, Hughes \& Caffesse 1978, Lindhe et al. 1973, 1975, Listgarten et al. 1978, Rosling et al. 1976, Theilade et al. 1966, Waerhaug 1978b). Subgingival calculus removal and root planing is difficult technically and often it is inadequately performed (Frumker \& Gard- ner 1956, Jones et al. 1972, Jones \& O'Leary 1978, Rabbani et al. 1981, Schaffer 1956, Waerhaug 1975, Waerhaug 1978a, Waerhaug 1978b, Walker 1976).

A great number of studies (Frumker \& Gardner 1956, Jones et al. 1972, Jones \& O'Leary 1978, Schaffer 1956, Walker \& Ash 1976) have shown that despite the best efforts of different clinicians to thoroughly root plane teeth, considerable amounts of calculus remained, although the surface was clinically smooth (Waerhaug 1978b). Investigations have shown that incomplete calculus removal may be discovered after periodontal flap procedures (Waerhaug 1975, Waerhaug $1978 \mathrm{a}$, b). It has been observed that complete removal of plaque and calculus was more difficult in deep pockets than in shallow pockets (Lovdal et al. 1961, Rabbani et al. 1981, Waerhaug 1978b). Tooth type did not influence the results obtained (Rabbani et al. 1981). Areas of calculus retention such as resorption bays, interradicular areas, the canine fossa of the upper first molar, the cemento-enamel junction, and carious defects (Jones et al. 1972) have been described. The use of explorer tips failed to differentiate between burnished calculus and cementum and appeared not to be an accurate means of assessing calculus removal (Jones \& O'Leary 1978, Rabbani et al. 1981).

The purpose of the present study was to evaluate the effectiveness of scaling and root planing on calculus removal, both with and without the use of a periodontal flap for access.

\section{Material and Methods}

The subjects were selected from patients scheduled for treatment at The University of Michigan School of Dentistry or the Veterans Administration Medical Center Dental Service in Ann Arbor, Michigan. All patients had been scheduled for immediate complete denture treatment. Extractions were deemed necessary due to periodontal disease. In order to participate in the study, the patients had to have at least 6 teeth 
of any type scheduled for extraction. A total of 21 patients (15 male, 6 female) ranging in age from 29 to 88 years (mean 52.7 years) participated in the study. None of the patients had previously received any periodontal treatment other than routine prophylaxis at a dentist's office.

After a thorough explanation of the purpose of the study, each patient was asked to sign a consent form. An assessment of the periodontal status was made for each patient by measuring pocket depth and the amount of calculus present. Prior to extraction, 2 of the 6 teeth were anesthetized, scaled and root planed. An inverted cone bur was used to mark the levels of the free gingival margin buccally and lingually on all teeth to allow differentiation between supra- and subgingival calculus. A mucoperiosteal flap was raised and 2 of the remaining 4 unscaled teeth were scaled and root planed. The two remaining teeth were left unscaled and served as control.

Since no significant difference in effectiveness of scaling had previously been found among different types of teeth (Rabbani et al. 1981), any tooth type was deemed acceptable for use. Maxillary and mandibular incisors, cuspids, bicuspids and first and second molars, were included in the investigation. The total number of teeth was 127 (43 scaled, 42 flapped and 42 control teeth).

\section{Measurements}

Dental calculus was assessed according to the criteria of the PDI (Ramfjord 1967). The Marquis M-1 probe (Marquis Dental Manufacturing Company, Denver, Colorado 80206) was used for the detection of subgingival calculus.

Probing depth was measured from the free gingival margin to the bottom of the periodontal pocket. Measurements were made at 6 locations on each tooth (mesial-buccal, buccal, distal-buccal, distal-lingual, lingual and mesiallingual) with the Marquis M-1 periodontal probe which was graduated at 3 , 6,8 and $11 \mathrm{~mm}$.

The buccal and lingual measurements were made at the midline of the tooth, while all other measurements were made as close as possible to the interproximal contact areas of the teeth with the probe pointed in an axial direction. The measurements were rounded to the nearest $\mathrm{mm}$; however, measurements close to $0.5 \mathrm{~mm}$. were rounded to the lower whole number.

\section{Experimental protocol}

The experimental procedures were performed in the following order.

1. Review of the patient's medical history.

2. Calculus was scored according to the PDI (Ramfjord 1967).

3. The pocket depths were measured on the 6 surfaces of the experimental and control teeth.

4. Local anesthesia ( $2 \%$ lidocaine, 1:100.000 epinephrine) was administered by infiltration or block to anesthetize the teeth and gingiva.

5. The teeth were marked circumferentially at the level of the free gingival margin with the high speed handpiece and the inverted cone bur.

6. 2 of the experimental teeth were scaled and root planed thoroughly with hand instruments in an attempt to remove all supra- and subgingival plaque and calculus.

7. A buccal and lingual mucoperiosteal flap was raised relative to 2 of the remaining 4 teeth and the teeth were scaled and root planed thoroughly with hand instruments in an attempt to remove all supra- and subgingival plaque and calculus.

8. The teeth were extracted in the Oral and Maxillofacial Surgery Department at The University of Michigan School of Dentistry or in the Dental Service at the Vesterans Administration Medical Center immediately after completion of the scaling and root planing of the flapped teeth.

\section{Preparation of teeth}

1. After the teeth were extracted, they were immediately rinsed with running water to remove surgical hemorrhage.

2. Soft tissue tags were removed.

3. The teeth were transferred to $1 \%$ methylene blue for $2 \mathrm{~min}$. This solution stained the connective tissue attached to the teeth.

4. The teeth were rinsed with running water for 2 to $3 \mathrm{~min}$.

Table 1. \%s of initial surface calculus scores and probing depths

\begin{tabular}{lcccrr}
\hline & \multicolumn{2}{c}{ Calculus (PDI) } & \multicolumn{3}{c}{ Probing depth (mm) } \\
& 2 & 3 & $1-3$ & $3-6$ & $76.0 \%$ \\
\hline scaling only & $30.2 \%$ & $69.8 \%$ & $26.2 \%$ & $55.8 \%$ & $18 \%$ \\
scale with flap & $33.3 \%$ & $66.7 \%$ & $25.6 \%$ & $66.1 \%$ & $8.3 \%$ \\
control & $33.1 \%$ & $61.9 \%$ & $20.2 \%$ & $57.1 \%$ & $22.6 \%$ \\
\hline
\end{tabular}

\section{Assessment of calculus under a stereomicroscope}

The teeth were viewed under a stereomicroscope (J. M. Stereomicroscope, Olympus Optical Company, Ltd. Tokyo, Japan) with a magnification of 6.3 / 12.5. The calculus present was measured on 4 surfaces (buccal, lingual mesial and distal) using a Whipple Net Micrometer Disc (Micrometer Disc for Model J. M. Microscope, Olympus, Tokyo, Japan), $10 \mathrm{~mm} \times 10 \mathrm{~mm}$ square subdivided into 100 squares, which was placed on the eyepiece of the stereomicroscope. The 4 surfaces were separated by placing a small scratch with a curette on each line angle of the tooth, from the areas of the gingival landmark (bur mark) to the line of the connective tissue attachment. Based on the view in the stereomicroscope, the total number of squares, which covered each surface of the tooth from the connective tissue attachment to the free gingival margin scratch, were added. The number of squares with calculus, for each of the surfaces, were then counted and added. This represented the total number of squares with calculus. In the assessment of calculus, the presence of calculus in each square of the tenth grid was counted as one, even if it was seen as a very small piece or fragment (Rabbani et al. 1981).

\section{Statistical analysis}

MIDAS (Michigan Interactive Data hypothesis that there was no difference in the affectiveness of subgingival scaling and root planing with or without a flap for access. The \% of remaining calculus was compared among experimental groups in relation to pocket depth and tooth type. the data was the $\chi^{2}$ test.

When attempting to relate $\%$ calculus and pocket depth, the following modification was performed: The pocket depth was measured at 6 locations on each tooth. However, the \% of calculus remaining was computed for 4 surfaces Analysis System) was used to test the

The statistical test utilized to evaluate 
Table 2. Frequency distribution and $\%$ of residual calculus in the 3 groups

\begin{tabular}{|c|c|c|c|c|c|c|c|c|c|}
\hline & $N$ & \multicolumn{6}{|c|}{$\%$ residual calculus } & \multicolumn{2}{|c|}{$>20 \%$} \\
\hline scale & 170 & 89 & $52.4 \%$ & 33 & $19.4 \%$ & 29 & $17.1 \%$ & 19 & $11.2 \%$ \\
\hline control & 166 & 11 & $6.6 \%$ & 8 & $4.8 \%$ & 12 & $7.2 \%$ & 135 & $81.3 \%$ \\
\hline total & 504 & 228 & & 62 & & 54 & & 160 & \\
\hline
\end{tabular}

$\chi^{2}: 309.59$; significance: 0.00001 .

of each tooth (buccal, lingual, mesial and distal) under the stereomicroscope. In order to make the pocket depth measurements and the calculus scores comparable for a given surface, the average of mesiobuccal and mesiolingual and also the average of distobuccal and distolingual pocket depth measurements were calculated and the means used for comparison with the calculus scores for these surfaces.

\section{Results}

The frequency distributions of initial PDI calculus scores (Ramfjord 1967) and probing depths are presented in Table 1.

Table 2 represents the frequency distribution and $\%$ of residual calculus for the 3 groups analyzed. Results show statistically significant differences between the 3 groups in the amount of residual calculus. A $\chi^{2}$ test was also performed comparing the $\%$ of residual calculus between the 2 treatment groups only. The results showed a statistically significant difference between calculus remaining after scaling only as compared to scaling with a flap $(P<0.0001)$.

Table 3 shows the $\chi^{2}$ test comparing probing depth to $\%$ of residual calculus for both treatment groups tested. There is a highly significant relationship between pocket depth and \% of residual calculus.

Table 4 relates probing depth and \% of residual calculus using only the surfaces from individual treatment groups. The $\chi^{2}$ tests for surfaces scaled only, or scaled with a flap, indicates that the $\%$ of residual calculus is dependent on probing depth in both instances. The probability of leaving residual calculus is increased at deeper probing depths.

Table 5 shows the $\chi^{2}$ test comparing anterior and posterior teeth against \% of residual calculus using only those surfaces which were scaled only. The $\chi^{2}$ test demonstrates that tooth type had no relationship to $\%$ of residual calculus
Table 3. Frequency distribution and \% of residual calculus related to probing depths for treatment groups

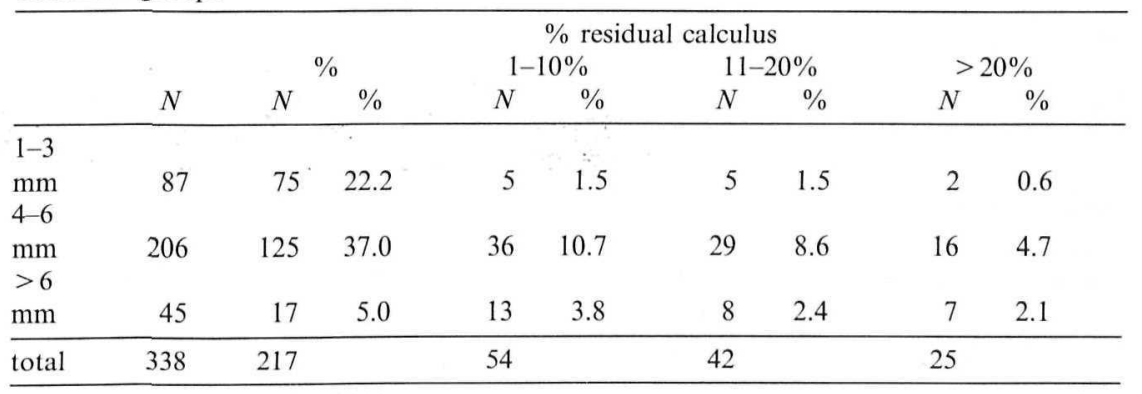

$\chi^{2}: 34.296$; significance: 0.00001 .

Table 4. Frequency distribution of residual calculus according to probing depth for scaled and flapped surfaces

\begin{tabular}{|c|c|c|c|c|c|c|c|c|c|}
\hline \multirow{3}{*}{$\begin{array}{l}\text { Probing } \\
\text { depth } \\
1-3 \mathrm{~mm}\end{array}$} & \multirow{3}{*}{$\begin{array}{c}\% \text { residual } \\
\text { calculus }\end{array}$} & \multicolumn{4}{|c|}{ Scaled } & \multicolumn{4}{|c|}{ Flapped } \\
\hline & & \multicolumn{2}{|c|}{$0 \%$} & \multicolumn{2}{|c|}{$>1 \%$} & \multicolumn{2}{|c|}{$0 \%$} & \multicolumn{2}{|c|}{$>1 \%$} \\
\hline & & 38 & 86.4 & 5 & 13.6 & 37 & 86.0 & 6 & 14.0 \\
\hline $4-6 \mathrm{~mm}$ & & 41 & 43.2 & 54 & 56.8 & 84 & 75.7 & 27 & 24.3 \\
\hline$>6 \mathrm{~mm}$ & & 10 & 32.3 & 21 & 67.7 & 7 & 50.0 & 7 & 50.0 \\
\hline total & & 89 & & 81 & & 128 & & 40 & \\
\hline
\end{tabular}

Table 5. Frequency distribution and \% of residual calculus for scaled surfaces: anterior versus posterior

\begin{tabular}{lccccc}
\hline & & \multicolumn{4}{c}{$\%$ residual calculus } \\
& $N$ & $0 \%$ & $1-10 \%$ & $11-20 \%$ & $>20 \%$ \\
\hline anterior & 92 & 49 & 19 & 16 & 8 \\
posterior & 78 & $28.8 \%$ & $11.2 \%$ & $9.4 \%$ & $4.7 \%$ \\
& & 40 & 14 & 13 & 11 \\
\hline total & 170 & $83.5 \%$ & $8.2 \%$ & $7.6 \%$ & $6.5 \%$ \\
\hline
\end{tabular}

$\chi^{2}: 1.3076$; significance: 0.7273 .

Table 6. Frequency distribution and \% of residual calculus for flapped surfaces: anterior versus posterior

\begin{tabular}{lccccc}
\hline & & \multicolumn{4}{c}{$\%$ residual calculus } \\
& $N$ & $0 \%$ & $1-10 \%$ & $11-20 \%$ & $>20 \%$ \\
\hline anterior & 84 & 61 & 11 & 7 & 5 \\
posterior & 84 & $36.3 \%$ & $6.5 \%$ & $4.2 \%$ & $3.0 \%$ \\
& & 67 & 10 & 6 & 1 \\
total & 168 & 128 & $6.0 \%$ & $3.6 \%$ & $0.6 \%$ \\
\hline
\end{tabular}

$\chi^{2}: 3.0725$; significance: 0.3806 . 
Table 7. Frequency distribution and column $\%$ of surfaces without remaining calculus related to pocket depth for treated groups

\begin{tabular}{lccc}
\hline & $N$ & $\begin{array}{c}\text { Scale } \\
\text { only }\end{array}$ & $\begin{array}{c}\text { Scale } \\
\text { with flap }\end{array}$ \\
\hline $1-3 \mathrm{~mm}$ & 75 & 38 & 37 \\
& & $42.7 \%$ & $28.9 \%$ \\
$4-6 \mathrm{~mm}$ & 125 & 41 & 84 \\
& & $46.1 \%$ & $65.6 \%$ \\
$>6 \mathrm{~mm}$ & 17 & 10 & 7 \\
& & $11.2 \%$ & $5.5 \%$ \\
\hline total & 217 & 89 & 128 \\
\hline
\end{tabular}

$\chi^{2}: 8.603$; significance: 0.0135 .

remaining on teeth which are scaled without a flap. Table 6 shows the same test using only those surfaces which had been treated with a periodontal flap procedure. The results here are no different, since again, tooth type had no bearing on whether residual calculus remained following periodontal flap surgery.

Table 7 compares the number of surfaces with no residual calculus, with scaling only and scaling with a flap, in relation to probing depth. The $\chi^{2}$ test reveals that the chance of removing all calculus is dependent on probing depth.

Fig. 1 shows the $\%$ of surfaces totally free of calculus for each group at the given levels of probing depths. Fig. 2 demonstrates the $\%$ of total surfaces for

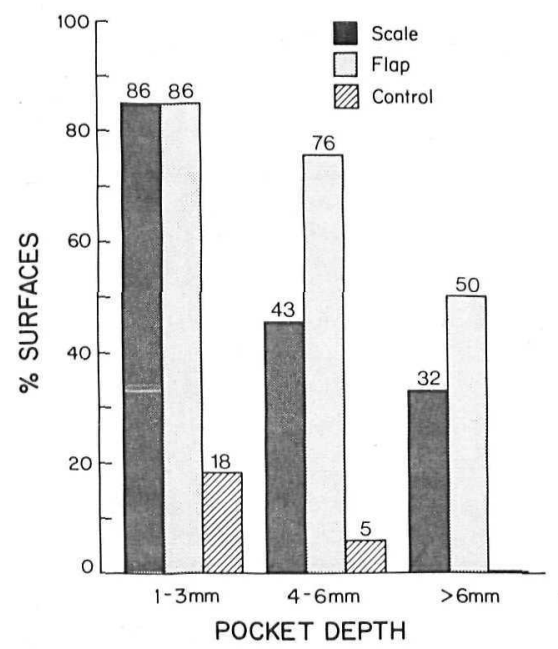

Fig. 1. \% distribution of surfaces with all calculus removed.

Die prozentuale Verteilung zahnsteinfreier Oberflächen auf die Taschentiefen.

Distribution (\%) des surfaces d'où tout le tartre a été éliminé.

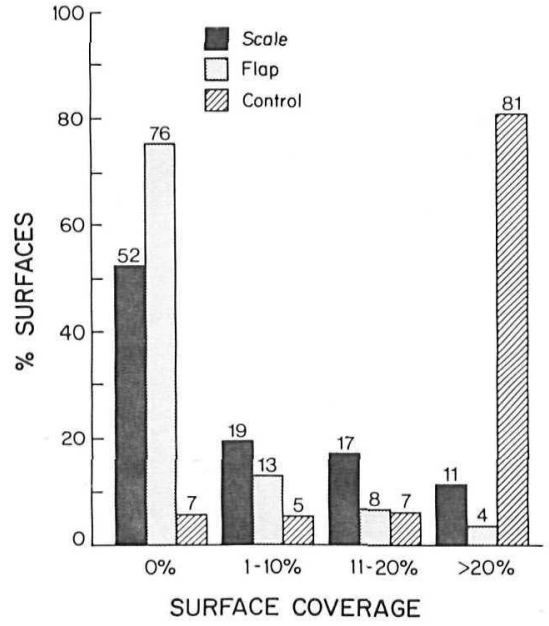

Fig. 2. \% distribution of total surfaces according to $\%$ remaining calculus.

Die prozentuale Verteilung aller Oberflächen auf das prozentuale Vorkommen von RestZahnstein.

Distribution (\%) de l'ensemble des surfaces suivant l'étendue (\%) du tartre restant.

each experimental group according to the level of remaining calculus.

\section{Discussion}

Histological studies (Caton \& Zander 1979, Waerhaug 1978a) have demonstrated that the healing of the dentoepithelial junction following subgingival plaque control resulted in the formation of a long junctional epithelim in areas previously covered with subgingival plaque and calculus. It has also been demonstrated that complete calculus removal is technically very difficult. Jones et al. (1972) root planed teeth in vivo until roots were smooth to an explorer. Subsequent examination with a scanning electron microscope revealed numerous residual calculus deposits. Schaffer (1956) reported that teeth routinely scaled and root planed were found to have deposits remaining, especially in surface defects. Frumker et al. (1956) found retained calculus deposits on extracted teeth and concluded that, due to the topography of the root surface, it might be difficult to remove all calculus present. The findings of the present study are in agreement with the aforementioned authors.

Jones et al. (1972) described differences in the step height level of calculus deposits from the root surfaces and reported that these varied between 5 to 56 $\mu \mathrm{m}$. In order to detect these deposits, every $\mu \mathrm{m}^{2}$ of the surface would need to be explored. They concluded that once a surface had been instrumented, it was not always possible to differentiate clinically among calculus, cementum, and dentin. Rabbani er al. (1981) also noted that considerable amounts of calculus were found to be retained over areas judged clinically smooth. This result is in agreement with the present findings. In the present study, teeth were scaled and root-planed only, while another group of teeth were scaled and rootplaned using periodontal flap surgery until the surfaces were judged clinically smooth to a periodontal probe or \#17 explorer. Although there was a significantly greater reduction of residual calculus in the group using flap surgery over teeth scaled alone, in neither group was complete calculus removal attained for all surfaces.

Part of the rationale for periodontal flap surgery is to improve healing by facilitating access for, and subsequently achieving, a more thorough root planing. Waerhaug (1975) reported that following flap surgery for access, deposits were found which had been left near the bottom of the pocket. Reasons for failure of complete removal of deposits with flap surgery have been described as bleeding, which obscures the field of operation close to the bottom of the pocket, and the fact that the plaque front and the tooth are of the same color (Waerhaug 1978b). Although complete calculus removal was not accomplished on all surfaces with the flap procedure, the assessment of remaining calculus demonstrated that scaling in conjunction with a periodontal flap was significantly more effective than scaling and rootplaning alone.

Rabbani et al. (1981) evaluated the effectiveness of subgingival scaling and root planing related to depth of pocket. Results of the study demonstrated a high correlation between $\%$ of residual calculus and probing depth on scaled and control teeth. Pockets less than 3 $\mathrm{mm}$ were the easiest sites for scaling and root planing, probing depths ranging from 3 to $5 \mathrm{~mm}$ were more difficult, and pockets deeper than $5 \mathrm{~mm}$ were the most difficult. This is in agreement with Waerhaug (1978b), who stated that in pockets less than $3 \mathrm{~mm}$, success could be expected, but the chances of failure increased in 3 to $5 \mathrm{~mm}$ pockets, while with probing depths greater than $5 \mathrm{~mm}$, the chances of failure dominated. The 
present study demonstrated that this significant relationship between increased probing depth and increased \% of surfaces with residual calculus existed not only on teeth treated by scaling alone, but also on teeth treated by flap surgery followed by scaling and root planing.

Rabbani et al. (1981) reported that in pockets less than $3 \mathrm{~mm}$, complete calculus removal occurred in $75 \%$ of the teeth, but in pockets deeper than 3 $\mathrm{mm}$, complete calculus removal occurred in only $18 \%$ of the teeth. Results from the present study demonstrated that in 1 to $3 \mathrm{~mm}$ pockets, $86 \%$ of all surfaces were completely cleaned of all deposits in both the scaled only group and the group in which a flap approach was used. This therefore denonstrates that in shallow 1 to $3 \mathrm{~mm}$ probing depths, scaling without flap surgery is just as beneficial in terms of calculus removal as scaling in conjunction with a flap.

However, the benefits of scaling with flap surgery become much more obvious in cases with deeper probing depths. In 4 to $6 \mathrm{~mm}$ pockets, only $43 \%$ of all surfaces were completely cleaned of all deposits on teeth which were scaled only, while $76 \%$ of all surfaces were completely cleaned in the teeth with flap surgery. In probing depths greater than $6 \mathrm{~mm}$, the ratio of surfaces completely cleaned of all deposits was $32 \%$ for scaled only, versus $50 \%$ for those treated with flap surgery plus scaling and rootplaning. Although these ratios show a large number of surfaces with at least some amount of deposits remaining following flap surgery, many of these teeth, especially those with probing depths greater than $6 \mathrm{~mm}$, were hopeless, with loss of attachment to the apex of the teeth. This made treatment difficult due to mobility, profuse bleeding, etc. Even so, scaling with a flap for access was significantly better than treatment with scaling and root planing alone in pockets deeper than $3 \mathrm{~mm}$.

Rabbani et al. (1981) have reported that there was not a statistically significant difference in the $\%$ of residual calculus on different types of teeth. Findings in the present study agree with this observation in both the group treated by scaling with or without a flap.

The assessment of calculus demonstrated that the CEJ was probably the greatest area of calculus retention in the group treated with flap surgery. Grooves, fossae, and furcation areas also re- tained reidual calculus, especially in the scaled only group. Another area of calculus retention was immediately below restorations, which was demonstrated in both treatment groups. Overall however, the scaled only group had more calculus retained on smooth surfaces as shown by the present results, while in the flapped group, remaining calculus was almost always associated with some sort of surface concavity.

\section{Conclusions}

Within the limits of this study, using a stereomicroscope to evaluate scaling effectiveness, the following conclusions can be drawn.

1. Periodontal flaps for access provide a means for greater reduction of residual calculus.

2. Periodontal flaps for access provide a means to achieve more tooth surfaces free of calculus in pockets $>3$ $\mathrm{mm}$.

3. The $\%$ of residual calculus is related to probing depth, despite the treatment approach.

4. Anterior and posterior teeth respond similiarly.

\section{Zusammenfassung}

Zahnsteinentfernung und Wurzelglättung mit und ohne parodontale Lappenchirurgie

Vollständige Konkremententfernung ist die wichtigste therapeutische Massnahme zur Erreichung »biologisch akzeptabler Oberflächen « bei der Parodontitisbehandlung. Rabbani und Mitarbeiter teilten 1981 mit, dass eine einmalige Zahnsteinbehandlung nicht imstande ist den subgingivalen Zahnstein völlig zu entfernen. Je tiefer die parodontale Tasche ist, umso weniger kann mit vollständiger Entfernung der harten Beläge gerechnet werden. Mit der hier vorliegenden Studie wurde beabsichtigt, die Effektivität der Konkremententfernung (scaling) im Vergleich zur Zahnsteinentfernung nach der Mobilisierung des parodontalen Lappens zu untersuchen. Bei 21 Patienten mit Indikationen zu multiplen Extraktionen wurde der Zahnstein an 2 Zähnen entfernt, an 2 Zähnen wurde die Zahnsteinentfernung erst nach der Aufklappung eines parodontalen Lappens vorgenommen und 2 Zähne dienten der Kontrolle. Die Behandlung wurde bei lokaler Anästhesie durchgeführt. Nach der von Rabbani beschriebenen stereomikroskopischen Methode wurde die konkrementfreie subgingivale Zahnoberfläche prozentual zur Gesamtfläche bestimmt. Die Resultate zeigten, dass bei der »nur«-Zahnsteinbehandlung (SO) und bei der Zahnsteinbehandlung mit Lappenaufklappung (SF) der prozentuale Anteil der Wurzelflächen ohne Zahnsteinanlagerungen anstieg
- die Lappenaufklappung erleichterte die Zahnsteinentfernung wenn die gingivalen Taschen $4 \mathrm{~mm}$ oder tiefer waren. Der Vergleich zwischen den beiden Behandlungsvarianten SO und SF bei verschiedenen Taschentiefen ergab bei Taschen von 1-3 mm Tiefe eine Zahnsteinfreiheit von $86 \%$ der Gesamtwurzeloberfläche bei SO und $86 \%$ bei SF; bei 4-6 mm Taschen $43 \%$ (SO) und $76 \%$ (SF) und bei Taschen $\geq 6 \mathrm{~mm}$ war das Verhältnis zwischen SO und SF $32 \%$ zu 50\%. Die Menge Residualzahnstein war direkt abhängig von der Taschentiefe und sie war höher nach der "nur"-Zahnsteinentfernung und kam am häufigsten an der Schmelzzementgrenze oder im Anschluss an Grübchen, fossae oder Furkationen (Wurzelteilungsstellen) vor Zwischen Vorder- und Seitenzähnen oder zwischen der verschiedenen Zahnoberflächen wurden keine Unterschiede gesehen.

\section{Résumé}

Détartrage et surfaçage radiculaire avec et sans intervention de chirurgie parodontale à lambeau

L'ablation complète du tartre constitue une partie primordiale des mesures prises pour obtenir une surface dentaire «biologiquement acceptable» dans le traitement de la parodontite. Rabbani et al. ont rapporté qu'un détartrage unique n'éliminait pas entièrement le tartre sous-gingival et que cette ablation était d'autant moins complète que la poche parodontale était plus profonde. Le but de la présente étude était d'évaluer l'efficacité du détartrage, comparé à l'ablation du tartre après réclinaison d'un lambeau parodontal. Chez 22 patients pour qui de multiples extractions étaient indiquées, on a, chez chacun d'eux, fait un détartrage sur 2 dents, un détartrage après réclinaison d'un lambeau parodontal sur 2 autres dents et utilisé 2 dents comme témoins. L'intervention a été faite sous anesthésie locale. Après les extractions, on a déterminé la proportion ( $\%$ ) des surfaces dentaires sous-gingivales exemptes de tartre par la méthode décrite par Rabbani, au stéréomicroscope. Il ressort des résultats que, tandis que le détartrage seul ( $\mathrm{SO}=$ scale only) et le détartrage avec lambeau ( $\mathrm{SF}=$ scale with flap) augmentent le \% de surface radiculaire exempte de tartre, le détartrage après réclinaison d'un lambeau facilitait l'ablation du tartre dans les poches de $4 \mathrm{~mm}$ et plus. En comparant $\mathrm{SO}$ et SF du point de vue du \% de faces dentaires entièrement exemptes de tartre dans le cas des différentes profondeurs de poche, on constatait qu'il y avait $86 \%$ versus $86 \%$ de poches de 1 à $3 \mathrm{~mm}, 43 \%$ versus $76 \%$ de poches de 4 à $6 \mathrm{~mm}$ et $32 \%$ versus $50 \%$ de poches $>6 \mathrm{~mm}$. L'étendue du tartre restant était directement en relation avec la profondeur des poches, était plus grande dans les cas de détartrage seul et était maximum au niveau de la jonction émail-cément (CEJ) ou au niveau des sillons, fossess ou furcations. Aucune différence n'á été notée entre les dents antérieures et postérieures ni entre les differentes faces des dents. 


\section{References}

Aleo, J. J. \& Vandersall, D. C. (1980) Cementum: recent concepts related to periodontal disease therapy. Dental Clinics of North America 24, 627-650.

Axelsson, P. \& Lindhe, J. (1978) Effect of controlled oral hygiene procedures on caries and periodontal disease in adults. Journal of Clinical Periodontology 5, 133-151.

Caton, J., Proye, M. \& Polson, A. (1982) Maintenance of healed periodontal pockets after a single episode of root planing. Journal of Periodontology 53, 420-424.

Caton, J. G. \& Zander, H. A. (1979) The attachment between tooth and gingival tissues after periodic root planing and soft tissue curettage. Journal of Periodontology 50, 462-466.

Frumker, S. C. \& Gardner, W. M. (1956) The relation of the topography of the root surface to the removal of calculus. Journal of Periodontology 27, 292-295.

Hughes, T. P. \& Caffesse, R. G. (1978) Gingival changes following scaling, root planing, and oral hygiene. A biometric evaluation. Journal of Periodontology 49, 245-252.

Jones, S., Lozdan, J. \& Boyde, A. (1972) Tooth surfaces treated in situ with periodontal instruments: Scanning electron microscopic study. British Dental Journal 132, 57-64.

Jones, W. A. \& O'Leary, T. J. (1978) The effectiveness of in vivo root planing in removing bacterial endotoxin from the roots of periodontally involved teeth. Journal of Periodontology 49, 337-342.

Lindhe, J., Hamp, S.-E. \& Loe, H. (1973) Experimental periodontitis in the Beagle dog. Journal of Periodontal Research 8, 1-10.

Lindhe, J., Hamp, S.-E. \& Loe, H. (1975) Plaque induced periodontal disease in Beagle dogs. A 4 year clinical roentgenographical and histometrical study. Journal of Periodontal Research 10, 243-255.

Listgarten, M. A., Lindhe, J. \& Hellden, L. (1978) Effect of tetracycline and/or scaling on human periodontal disease. Clinical microbiological and histological observations. Journal of Clinical Periodontology 5, 246-271.

Loe, H., Theilade, E. \& Jensen, S. B. (1965) Experimental gingivitis in man. Journal of Periodontology 36, 177-187.

Lovdal, A., Arno, A., Schei, O. \& Waerhaug, J. (1961) Combined effect of subgingival scaling and controlled oral hygiene on the incidence of gingivitis. Acta Odontologica Scandinavica 19, 537-555.

Rabbani, G. M., Ash, M. M. \& Caffesse, R. G. (1981) The effectiveness of subgingival scaling and root planing in calculus removal. Journal of Periodontology 52, 119-123.

Ramfjord, S. P. (1967) Periodontal disease index (PDI). Journal of Periodontology 38, 602-610.

Rosling, B., Nyman, S., Lindhe, J. \& Jern, B. (1976) The healing potential of the periodontal tissues following different techniques of periodontal surgery in plaque-free dentitions. A two year clinical study. Journal of Clinical Periodontology 3, 233-250.

Theilade, E., Wright, W., Borglum-Jensen, S. \& Loe, H. (1966) Experimental gingivitis in man II. A longitudinal clinical and bacteriological investigation. Journal of Periodontal Research $1,1-13$.

Schaffer, E. M. (1956) Histological results of root curettage of human teeth. Journal of Periodontology 27, 296-300.

Waerhaug, J. (1956) Effect of rough surfaces upon gingival tissues. Journal of Dental Research 35, 323-325.

Waerhaug, J. (1975) A method of evaluation of periodontal problems on extracted teeth. Journal of Clinical Periodontology 2, 160-168.

Waerhaug, J. (1978a) Healing of the dentoepithelial junction following subgingival plaque control. I. As observed in human biopsy material. Journal of Periodontology 49, 1-8.

Waerhaug, J. (1978b) Healing of the dentoepithelial junction following subgingival plaque control. II. As observed on extracted teeth. Journal of Periodontology 49, 119-134.

Walker, A. \& Ash, M. M. (1976) A study of root planing by scanning electron microscopy. Dental Hygiene 50, 109-114.

Address:

R. G. Caffesse

Department of Periodontics

The University of Michigan School of Dentistry

Ann Arbor, Michigan 48109

USA 
This document is a scanned copy of a printed document. No warranty is given about the accuracy of the copy. Users should refer to the original published version of the material. 